\title{
SELF-EVALUATION AND SCHOOL IMPROVEMENT: THE ISSEMOD MODEL TO DEVELOP THE QUALITY OF SCHOOL PROCESSES AND OUTCOMES Davide Capperucci ${ }^{*}$
}

\author{
Prof., University of Florence, ITALY, davide.capperucci@unifi.it
}

\begin{abstract}
Recent European and North American government policies, implementing new systems of evaluation and accountability, have highlighted the use of performance data to inform judgments about schools and stimulate school improvement. This has led to the implementation of school self-evaluation considered as an effective means to increase school quality and effectiveness. Decentralization of education systems, which is the official policy in many European countries, has evoked increased interest in accountability, responsiveness and self-improvement of schools. This trend has promoted, on the one hand a broadening of educational evaluation methodologies and, on the other, a conceptualization of theoretical approaches and research in the field of school effectiveness and improvement. A viable working definition, also used in this research, is that school self-evaluation concerns a type of educational evaluation that is initiated at school level and, at least partially, controlled by the school itself.

This study presents a self-evaluation model, called the ISSEMod, thought to improve school accountability, applicable in different countries, combining central control managed by public authorities (external control) and the autonomy reserved for schools related to pedagogical, instructional and organizational practices (internal control). Using a sample of 58 Tuscan schools, an empirical and evidence-based model of school self-evaluation focused on a flexible system of areas and indicators to investigate and analyse school quality, is proposed here.
\end{abstract}

Keywords: self-evaluation, school effectiveness, quality assurance, accountability, learning organizations

\section{INTRODUCTION}

The last two decades have shown a transition in the governance strategy of national governments combining devolution of authority, administrative autonomy and a strong emphasis on the quality of education. New models of school regulations based upon accountability measures, and evaluation practices, have received considerably more attention (Olssen, Codd and O' Neill, 2004). Such models have led to the development of national educational policies that include standards for school performances, external student assessment, internal and external evaluations, and the development of best practices. These educational policies point to 
two different approaches to accountability: a so-called government-based versus a market-based accountability approach. As demonstrated by the recent Eurydice report (2015), the improvement of quality in education has become the central concern of educational policy in many European countries. Several European and North-American countries have completed - or are working on - legislation and monitoring in the field of school self-evaluation (SSE), giving a lot of consideration to their responsibility for quality.

A system of school self-evaluation can be considered from several positions depending on the school's goals, ranging from a restricted view that focuses purely on the school's outcomes, to a broad perspective in which school assessment is focused on input, internal processes at school and classroom level as well as performance. In this second case, the analysis may include context, input, processes and output. This is the approach that has been adopted in the present work.

\section{EFFECTIVE SCHOOLS AND QUALITY OF EDUCATION}

The last 20 years has witnessed a rapid growth in the areas of research and practice covering the fields of school effectiveness and improvement. Research on the "effective schools movement" can be regarded as those ones that more than others have touched the core of school effectiveness. In Coleman \& Jencks' surveys, the inequality of educational opportunity was the central problem and the school was even conceived as a "black box" (Coleman et al., 1966). Effective school research is generally regarded as a response to the results of studies from which it was concluded that schools did not matter very much when it came down to differences in levels of achievement. From the studies conducted by Brookover and Mortimore (Brookover et al., 1979; Mortimore et al., 1988), instead, it appears that the most distinguishing feature of effective schools research was the fact that it attempted to break open the "black box" of the school by studying characteristics related to organization, form and content of schools. The results of the early effective schools research converged around five factors: 1 . strong educational leadership; 2 . emphasis on the acquisition of basic skills; 3 . an orderly and secure environment; 4 . high expectations of pupil attainment; 5 . frequent assessment of pupil progress (Scheerens, 2000).

Today the term "school effectiveness" has come to be used to describe educational research concerned with exploring differences within and between schools. Its principal aim is to obtain knowledge about relationships between "explanatory" and "outcome" factors using appropriate models. In its basic form, it involves choosing an outcome and then studying average differences among schools after adjusting for any relevant factors such as the intake achievements of the students. Researchers are interested in such things as the relative size of school differences and the extent to which other factors, such as student social background, curriculum organization, teaching methods and school management, may explain differences.

It is, however, important to recognize that school effectiveness research results do not provide recipes for the creation of more effective schools (Creemers, 1994). School improvement efforts require a particular focus on the processes of change and understanding of the history and context of specific institutions (Stoll and Fink, 1996). Whilst it is recognized that, in many ways our knowledge of what makes a "good" school, greatly exceeds our knowledge of how to apply that knowledge in programmes of school improvement, there is growing acceptance that such research provides a valuable background and useful insights for those concerned with improvement (Reynolds, Teddlie, Hopkins and Stringfield, 2000). The findings should not, however, be applied mechanically and without reference to a school's particular context. Rather, they can be seen as a helpful starting point for school self-evaluation and review.

Although Reid, Hopkins \& Holly (1987, p. 22) concluded that "while all reviews assume that effective schools can be differentiated from ineffective ones there is no consensus yet on just what constitutes an effective school", there is now a much greater degree of agreement amongst school researchers concerning appropriate methodology for such studies, about the need to focus explicitly on student outcomes and, in particular, on the concept of the "value-added" by the school (Lissitz, 2005). For example, Mortimore (1994) has defined an effective school as one in which students progress further than might be expected based on its intake. An effective school thus adds extra value to its students' outcomes in comparison with other schools serving similar intakes. Methodological developments have drawn attention to the need to consider issues of consistency and stability in effectiveness and the importance of caution in interpreting any estimates of individual school's effects.

A literature review identified the following key correlates of school effectiveness: 1. professional leadership; 2. shared vision and goals; 3 . learning environment; 4 . concentration on teaching and learning; 5 . purposeful teaching; 6. high expectations; 7. positive reinforcement; 8. monitoring progress; 9. pupil rights and responsibilities; 10. home-school partnership; and 11. a learning organization. The majority of effectiveness studies have focused exclusively on students' cognitive outcomes, but there is less evidence about school and classroom processes that are important in determining schools' success, in promoting social or affective outcomes (Reynolds, Teddlie, Hopkins and Stringfield, 2000).

The increasing sophistication of school effectiveness research has provided strong evidence that individual student background characteristics account for a much larger proportion of the total variance in students' 
academic outcomes than does the particular school attended. This is especially true of the impact of prior attainment. However, gender, socio-economic, ethnicity and language characteristics, which of course are also strongly correlated with prior attainment also, have a small but continuing influence (Sammons, 1994). During the last two decades a considerable body of research evidence has accumulated which shows that, although the ability and family backgrounds of students are major determinants of achievement levels, schools in similar social circumstances can achieve very different levels of educational progress (Mortimore, 1994). Such studies, conducted in a variety of different contexts, on different age groups, and in different countries confirm the existence of both statistically and educationally significant differences between schools in students' achievements (Hattie, 2009). Most school effectiveness studies have focused on academic achievement in terms of basic skills in reading and mathematics, or examination results (Goodlad, 1984). However, a few have also provided evidence of important differences in social/affective outcomes such as attendance, attitudes, and behaviour (Reezigt and Creemers, 2005).

Methodological advances, particularly the development of multilevel techniques have led to improvements in the estimation of school effects (Goldstein et al., 1993). These have enabled researchers to take better account of differences between schools in the characteristics of their pupil intakes, and facilitated exploration of issues such as consistency and stability in schools' effects upon different kinds of outcome as well as over time. In addition, multilevel techniques also allow investigation of the concept of differential effectiveness, and whether some schools are more or less effective for particular student groups (boys or girls, low or high ability students, those from specific ethnic groups).

Effective schools research also shows that monitoring pupil performance and progress at the school-level is a significant factor. Scheerens (2002), in a review of school effectiveness research, argued that proper evaluation is an essential prerequisite for effectiveness-enhancing measures at all levels. Evaluating school improvement programmes is particularly important. For example, Levine \& Lezotte (1990) emphasized the importance of the use of measures of pupil achievement as the basis for programme evaluation. It could be concluded that the feedback and incorporation of monitoring and evaluation information routinely into decision-making procedures in the school ensures that information is used actively.

\subsection{Theoretical models to evaluate schools' effectiveness}

School evaluation provides the identification and judgment of the quality of schools, as well as the improvement of their managerial and organizational effectiveness. These two aspects are relevant to this research as well. Hofman, Hofman, Gray \& Daly (2003) developed a framework for school evaluation using relevant standards from an accountability perspective and combined them with a school improvement perspective. This led to the use of the so-called CIPPO model (context, input, processes at school level, processes at classroom level, output) which is an adapted version of the "Context-Input-Process-Product model" (CIPP) that has been widely used in research into school and classroom quality management (Stufflebeam, 2000).

For the school improvement perspective, the framework adds theoretical organizational perspectives that focus on school development using a system of integral school evaluation as a starting-point (Dalin 1993; Reynolds and Teddlie, 2000; Stoll and Wikeley, 1998). In this process, four implementation stages for improvement reflect the Plan-Do-Check-Act cycle: the stage of orientation and preparation (plan phase), implementation (do phase), evaluation (check phase) and finally the institutionalization or integration (act/adapt phase).

Studies into effective school improvement offer knowledge on the matters schools should consider in relation to self-evaluation. These lead to three general theoretical perspectives regarding how school evaluation is developed or takes place in a certain school setting: 1 . school self-evaluation within schools as high-reliability organizations (Stringfield and Slavin, 2001; Hofman, Hofman and Guldemond, 2003); 2. school self-evaluation developed under pressure of external organizations (Hofman, Dukstra and Adriaan Hofman, 2005); 3. school self-evaluation within schools as learning organizations (Argyris and Schön, 1978; Carnall, 1990; Leithwood, Aitken and Jantzi, 2001).

These theories focus on different groups and perceptions in the schools as input for school evaluation.

1. The first theoretical approach views the school as a high-reliability organization which focuses on the pupils. In this type of school all members strive for perfection and presume the principle "trial without error" with an optimal school career for all pupils as their goal (Stringfield, Reynolds and Schaffer, 2001). The main idea is that an organization cannot afford to make mistakes; the consequences of a mistake would be disastrous for school staff, who would lose external credibility. The improvement of the quality of schools is related, in particular, to the following three factors: a) monitoring and use of extensive rich data, b) extensive recruiting of staff, training and retraining, c) mutual staff monitoring without loss of autonomy and confidence (Stringfield, Reynolds and Schaffer, 2001).

2. The second theoretical approach originates from contingency theory (Mintzberg, 1979) and includes the perspective that school evaluation is stimulated by the external community that surrounds a school. For 
example, schools can be stimulated or forced by the National or Local Educational Authority or by parents to evaluate and improve their quality. Reezigt \& Creemers (2005) use the term "external pressure" to describe one of the most important factors to stimulate school evaluation or, more specifically, school improvement. Choice and competition in education have found growing support among policy makers recently, especially after the institutionalization of many National Evaluation Systems, as has happened in most of the countries of Eastern and Southern Europe (including Italy) since the end of the Nineties. Yet, evidence on the actual benefits of market-oriented reforms have revealed their limitations, insofar as they are only geared to the satisfaction of external requests without paying attention to an educational project wanted and thought through at school level.

3. The third theoretical approach considers the school as a learning organization that focuses on the teaching staff and its ability to learn through interaction and peer exchange. Leithwood, Edge \& Jantzi (1999, p. 4) define this: as "a group of people pursuing common purposes (and individual purposes as well) with a collective commitment to regularly weighing the value of those purposes, modifying them when that makes sense, and continuously developing more effective and efficient ways of accomplishing those purposes". This definition sees the learning organization as a dynamic process, characterized by a low degree of hierarchy in between school staff and a widespread collaboration at all stages of the process. The goal is reaching not a static finish, but a continuous accentuation of purposes and means. In a learning organization, schools need to adapt to their context and population while giving shape to five aspects that promote collective learning identified by Leithwood, Aitken \& Jantzi (2001): 1. school vision and mission, 2. school culture, 3. school structure, 4. school strategies, 5. school policy and means.

The multilevel analysis has shown the relevance of the theory of schools as learning organizations. Schools typified as 'learning organizations' optimize the talents of the staff so they can contribute maximally to the quality of the school. Further these are schools with high innovative capacities, able and willing to respond optimally to contextual changes.

These analyses once again seem to support the theory that teachers, or more strongly the team of teachers, are the principal actors of the processes through which schools are stimulated to work towards school improvement. Further research must keep in mind that attention has to be paid to the schools' interpretations of an accountability policy, as well as to the processes in the school and classroom which constitute the implementation of such a policy. Although accountability policies are constructed at the central government level, they are, in the end, specifically school shaped by the different actors in the school. In fact, teachers' construction of understandings and interpretations are influenced by social interaction with colleagues as well as by characteristics of the school environment. A school that pays attention to its internal processes can stimulate teachers to a progressive improvement of their performances, thereby generating a progressive advancement of the entire organization.

\subsection{External evaluation versus internal evaluation: towards an integrated approach}

As already stated, in recent years, educational systems throughout Europe and in other parts of the world have seen great changes on many fronts, one of the most significant is the process of decentralisation which is related to school evaluation. This has been putting pressure on educational organizations to improve and develop good practices, turn problems into opportunities, promote what goes on in schools, and, in particular, raise students' achievement levels.

As reported by the authors mentioned hereafter, pressure for school improvement has been investigated through two approaches: (1) the quasi-market model and (2) the government-based accountability model.

1. The quasi-market model considers the pressure on school systems generated, at national and local level, from a rational consumer viewpoint in which competition among schools is perceived as the central channel for quality improvement (Creemers and Kyriakides, 2008). Within this approach strong parental school choice influences and stimulates the quality of schools, and, consequentially, their organizational aspects and the work related to the so-called academic achievements, because parents' school choice is based on these characteristics (Carnoy, Elmore and Siskin, 2003);

2. The government-based accountability model, instead, provides a sort of regulation by results (Harris and Herrington, 2006), but this is employed in education systems (e.g., several states in the USA, France, Portugal) in which educational authorities do not officially promote free school choice. In these settings, quality improvement is stimulated through external evaluation mechanisms. School reports give details on the basis of external assessment of pupils or on the basis of an internal audit of the organizational or educational processes within the school. This information is returned to the school staff in order to incite them to improve their performance.

These two approaches to school evaluation and accountability must be regarded as signs of the significance and chosen priorities of the government policy. However, in both cases it is crucial to investigate to what extent the chosen accountability policies are based only upon academic achievement within schools or, whether information is also included about the school's student population and classroom observations of the 
teaching and learning processes, as observed in some European countries and American States (Hofman, Dukstra and Adriaan Hofman, 2005; Ellet and Teddlie, 2003). These perspectives distinguish two main actors in school evaluation: an internal actor (schools), and an external one (National Evaluation Systems and Inspectorates of Education).

Beginning with the outcomes of the research mentioned above, in the last few decades it has also been possible to identify a third approach which highlights internal and external evaluation, seen as two different approaches to the same issue. Indeed, both globally and locally, there is recognition that both self-evaluation and external evaluation have complementary roles to play in improving the quality of students' learning (European Commission, 2004). From this perspective of school evaluation, the internal and external points of view are closely integrated and are fundamental also for the research presented in this paper, even though in this case more attention is given to self-evaluation. This third perspective focuses more specifically on the real practices, processes and viewpoints on school self-evaluation. Outcomes of theories of effective schools and effective management practices suggest that different approaches towards school self-evaluation are expected depending upon the focus of a school (e.g., the school as a team of teachers, the optimizing of the pupils' school career, external pressure for school evaluation, etc.).

For these and other reasons, in particular, the high costs of external inspection systems, the direction of school and teacher evaluation in many education systems is undoubtedly oriented towards internal evaluation and school based self-evaluation. In recent works on school evaluation, MacBeath (2003, p. 2) states that "self-evaluation is now seen as a matter of priority in most economically advanced countries of the world". Not by chance, MacBeath's statement has been appreciated by other authors and institutions. At a European level, for example, the Recommendation of the European Parliament and Council on European Cooperation in Quality Evaluation in School Education (2001) clearly argues that improvements in European school evaluation provision are dependent on the enhancement of schools' abilities to evaluate themselves. Specifically, the Recommendation calls on Member States of the EU to "encourage school self-evaluation as a method of creating learning and improving schools" (2001). This analysis is echoed in the recent highly influential OECD reports on the future of the teaching profession $(2005,2014 b)$. These reports see the development of self-evaluation skills within the education system as being a critical component in the drive to improve educational provision in OECD member states.

In response to schools' needs for quality improvement, today most accountability policies show an interesting combination of central control and steering by the countries' central government, with relative autonomy reserved for school governing bodies and individual schools. The literature on school evaluation recognizes the same importance for both the major functions of school evaluation (internal and external) (Newmann, King and Rigdon, 1997; Wilcox and Gray, 1996; Wastiau-Schlüter, 2004). The external function focuses on the safeguarding of standards of quality of schools, and in most European countries a National Inspectorate of Education is responsible for this task. In this respect, the government has strategic control over the goals of the education system, based upon standards, objectives and criteria of success regarding the outcomes of a school. At the same time, the daily management practices are left to the local schools' responsibility. The internal function is the responsibility of the schools themselves; schools are supposed to determine, guarantee, and safeguard their quality, as well as improve the teaching-learning process and school performance (Jakobsen, MacBeath, Meuret and Schratz, 2003; Janssesns and Van Amelsvoort, 2008). In general, several European countries acknowledge that the evaluation of their schools is at the very "heart of the quality of schooling", and this is a process which includes evaluation by an external Inspectorate, as well as internal procedures by the school community itself (Wastiau-Schlüter, 2004; European Commission, 2004).

Newmann, King \& Rigdon (1997) studied the connection between internal and external types of school accountability. They concluded that external accountability seems to strengthen the internal monitoring and use of evaluation systems within schools, and seems to encourage the search for success or failure in the schools' educational practices. Considering the outcomes of their European Pilot project "Quality evaluation in school education', MacBeath, Meuretz, Schratz \& Jakobssen (1999) present the clear message that internal and external evaluation are complementary processes in which the relation between the two should be clearly articulated. Outcomes of this European pilot project also seem to indicate that more is to be expected from a system of internal school self-evaluation than from an external focus (37\% of the schools in the project expect improvement in teaching from external while $55 \%$ from internal school self-evaluation). Thanks to self-evaluation, schools assume the role of real learning organizations. In this way, they become able to analyse the structure of internal processes and organizational models, identify strengths and weaknesses, revise instructional design and monitor specific learning outcomes. More recent research, conducted among European Union countries, shows an increasing use of integrated models of school evaluation. In fact, in 31 European education systems, schools carry out internal evaluation and are also examined by external evaluators. One widespread form of interdependence between the two processes is the use that external evaluators make of internal evaluation findings. In two thirds of the education systems where external and 
internal school evaluation coexist, internal evaluation findings are part of the information analysed during the preliminary phase of external evaluation (European Commission/EACEA/Eurydice, 2015).

\section{PROMOTING SCHOOL SELF-EVALUATION (SSE): A RESOURCE FOR SCHOOL IMPROVEMENT AND QUALITY DEVELOPMENT}

Scheerens (2002) defines school self-evaluation (SSE) as "the type of evaluation where the professionals that carry out the programme or core service of the organization carry out the evaluation in their own organization". In most of Europe, as Nevo's (2002) work shows, there is, a surprising emphasis on school autonomy and on self-regulation and internal evaluation as the best way forward.

A well planned school evaluation process helps to create an appropriate climate that can support school communities to address both internal and external demands. A systematic and holistic approach to school management and organization is necessary if development planning is to be perceived as one of the most significant tools to enhance efficiency, improve communication, and nurture a culture of collegiality and participation among all the different stakeholders. In this way, school self-evaluation becomes a mechanism through which a school can sustain itself to review the effectiveness of its work, with a view to quality education through continuous improvement. Akpe \& Afemikhe (1991, p. 118) consider SSE as "A planned and organized inquiry by institutional staff into the total work or effectiveness of institutional operations [...], a comprehensive and systematic evaluation effort carried out by the staff of the institution to determine its areas of strength and weakness [that] aims primarily at identifying problems and producing positive and desirable change in the institution". MacBeath (1999) suggests that SSE can serve six different purposes ranging from the political to issues of accountability, professional development, organization advancement, improvement of teaching, and enhancement of student learning. SSE promotes accountability and transparency of internal processes, by taking into consideration how schools use professional, financial and technical resources, how they increase decision-making procedures in the perspective of a continuous quality development. In an ideal world, school evaluation might be able to deliver on all of these goals simultaneously. In practice, however, what seems to be becoming clear is that these objectives are more competing than complementary; for this reason it is necessary to design a rigorous internal evaluation system, which can monitor, step by step, how schools can improve their outcomes and professional skills.

To promote a global and rigorous approach to school evaluation, during the last few decades school effectiveness researchers have given considerable attention to the production and use of "performance indicators", usually applied as measures of average school achievement scores. The difficulties and risks associated with performance indicators are now well recognized and are twofold. First, their use tends to be very narrowly focused on the task of ranking schools rather than on that of establishing factors which could explain school differences; secondly a number of studies have now demonstrated that there are serious and inherent limitations to the usefulness of such performance indicators for the provision of reliable judgements about institutions (Goldstein and Thomas, 1996). Briefly, the reasons for these limitations are as follows: 1. Given what is known about differential school effectiveness, it is not possible to provide simple one-dimensional summaries which capture all of the important features of institutions, therefore self-evaluation cannot be focused only on students' learning results but has to be extended to many other sectors and fields of school functioning (such as those considered in the Section 4.2). 2. From a methodological point of view, self-evaluation needs to be based on quantitative and qualitative data. When doing so, it is well known that by the time information from a particular institution has been analysed, it refers to a "cohort" of students who entered that institution several years previously so that its usefulness for future students may be dubious. Furthermore, it is increasingly recognized that institutions should be judged not by a single "cohort" of students, but rather on institutional performance over time.

Moreover, in coherence with a more comprehensive idea of self-evaluation, quality indicators cannot be limited just to student's outcomes, but have to consider also many others aspects related to context, inputs, processes and products. Even in those countries, such as the UK, where the applied tradition of external evaluation is very strong, since the mid-1990s internal evaluation is seen as the main driving force in terms of the evaluation of school and pupil performance. It seems that the processes and frameworks used as a basis for inspection have been modified so as to take greater account of a growing drive for internal, self-evaluation, arising from the desire of schools to assess for themselves how well they are doing (Earley et al., 1996).

West \& Hopkins (1997) emphasize the role of self-evaluation as school improvement. In this case, evaluation and improvement processes are two faces of the same constant monitoring activity. Self-evaluation becomes a sort of action-research aimed at exploring the reflexive potential of schools. For example, the fact that school teams look at the priorities and methods of a research for the strong and weak points of the school's functioning, may lead to improvement in the sense of increased awareness of educational goals and cooperation between staff. In fact, the implementation of school self-evaluation helps schools to develop an overview of how they are performing. In this respect, there is a dual purpose to school self-evaluation. Firstly, there is a professional development function aimed at training school staff in the applied use of methods of 
data collection, evaluation and analysis (McNamara and O'Hara, 2008). Secondly, the collection of evaluation data is, in itself, useful to schools so as to gain evidence from which to design future improvement plans. Such data can be used not only to see how pupils and teachers in a particular school are doing, but also to develop an overall picture of how the schools in a specific area are performing (Scheerens, Glas, Thomas and Thomas, 2003).

Thanks to self-evaluation, schools can develop their own agenda for evaluation, enabling teachers to focus on aspects of the school that they identify as areas for quality development. Furthermore, the internal agenda set within schools can also help to promote ownership among teachers of school self-evaluation activity. While it is clear that much of the impetus for self-evaluation is usually generated by head-teachers, particularly in the early stages, it is absolutely necessary to encourage teachers to become involved in this process. In this way, self-evaluation can be used to stimulate and motivate community involvement. Parents, pupils and governors can provide useful feedback, inform classroom practice and help to set the agenda for school change, accountability and effectiveness.

\section{THE ISSEMOD MODEL: A MULTIDIMENSIONAL APPROACH TO SCHOOL SELF-EVALUATION AND ACCOUNTABILITY}

\subsection{Research Context}

The recognition of school autonomy in strategic sectors such as didactics, organization and curriculum innovation, occurred in most European countries in the 1980s, and began at the end of the Nineties in Italy. This autonomy has generated two consequences which need to be considered: 1) the extension of decision-making powers and areas of flexibility available to each school as regards the design of training offer; 2) a strengthening of the responsibilities required of teachers and school leaders in parent and student educational needs' satisfaction (Woessmann, Luedemann, Schuetz and West, 2009).

In Italy, the self-evaluation of schools has assumed great importance as a result of the enactment of the new Regulation on National School Evaluation System (Decree n. 80/2013). This Regulation states the importance of the relationship between external evaluation and self-evaluation, creating a strong relationship between evaluation and improvement. The new Italian National School Evaluation System, in fact, is structured in four phases: 1) self-evaluation; 2) external evaluation; 3) design and implementation of improvement plans; 4) social accountability. In this System, self-evaluation is intended as a continuous analysis process of school practices and activities, and it is the first stage of an integrated evaluation for improvement, capable of analysing some processes, such as those ones at class level, which are more difficult to detect with external evaluation. In this system, external evaluation and the identification of criteria and tools for self-evaluation are used primarily to guide each school towards a systemic perspective of internal organization analysis, which is useful to recognize the essential components and mutual external-internal relations, as well as to read the individual case in comparison to others (Barzanò, 2002).

The final aim of the Regulation is to achieve a sort of equilibrium, a balance between internal and external evaluation, as happens in other European countries (Blok, Sleegers and Karsten, 2008). Self-evaluation is, therefore, the starting point for a multi-year process of analysis within-school that needs a rigorous evidencedbased methodology together with qualitative/quantitative tools of detection/measurement, which can provide reliable information on the processes in place as well as the results obtained (Coe, 2002).

\subsection{Research design and methodology}

The self-evaluation model presented in this paper is called ISSEMod (Integrated School Self-Evaluation Model), and it is a generative device that each school can adopt and adapt to its own context, and that can enrich the basic model established at national or local level. The model in question is based on a system of areas and indicators (SEAIS - Self-Evaluation Areas and Indicators System) through which schools can observe themselves and compare their results (organization, management, teaching resources, learning outcomes, etc.) with those of other schools that have the same socio-economic and family background. According to the above-mentioned theoretical framework of schools as "learning organizations" (Argyris and Schön, 1978) integrated with the latest research on school quality indicators conducted by the OECD (2014a), self-evaluation is here perceived as a means to investigate the "overall health of schools". Therefore, it is not limited only to monitor the outcomes of learning, but reflects on the ways of being of a school as a complex organization which is part of a broader context of external relations, by paying attention to the results achieved compared to targets set, and taking into account the resources available.

From the methodological point of view, it was decided to use the evidence-based approach (Thomas and Pring, 2004). This is considered the most suitable one to provide valid and reliable information on internal processes and results that schools make externally visible to their stakeholders, and furthermore, makes it possible to treat the outcomes obtained in a comparative perspective. Specifically, a system of areas and indicators (SEAIS) has been developed to analyse the quality of the actions taken, as well as to prepare an 
Integrated Self-Evaluation Report (ISER) on school strengths and weaknesses (Scheerens and Hendriks, 2004).

The ISSEMod Model is based on three dimensions: 1. Context and Resources; 2. Outcomes; 3. Processes (according to the well-known CIPPO Model - Context, Input, Processes at school level, Processes at classroom level, Output). Each dimension is described in specific areas as shown in Table 1. These areas are described by appropriate indicators to collect quantitative and qualitative data.

Table 1. School Self-Evaluation dimensions/fields, areas and indicators (SEAIS)

\begin{tabular}{|c|c|c|}
\hline Field & Area & Description \\
\hline \multirow{4}{*}{ 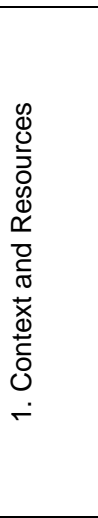 } & $\begin{array}{c}1.1 . \\
\text { School } \\
\text { population }\end{array}$ & $\begin{array}{l}\text { 1.1.1. Students' socio-economic and cultural backgrounds, characteristics of the } \\
\text { school population (e.g. employed, unemployed, immigration data, etc). }\end{array}$ \\
\hline & $\begin{array}{l}1.2 . \\
\text { Territory } \\
\text { and human } \\
\text { capital }\end{array}$ & $\begin{array}{l}\text { 1.2.1. Economic characteristics of the territory and its productive specialisation. } \\
\text { Resources and skills available in the community for cooperation, participation and } \\
\text { social interaction. Relevant local institutions and cultural agencies (e.g. for inclusion, } \\
\text { combating early school leaving, school and vocational orientation, training planning). }\end{array}$ \\
\hline & $\begin{array}{c}1.3 . \\
\text { Economic } \\
\text { and structural } \\
\text { resources }\end{array}$ & $\begin{array}{l}\text { 1.3.1. School budget, private company sponsorships, diversification of funding } \\
\text { sources (e.g. family and individual support for school activities, national and local } \\
\text { government financial commitment). } \\
\text { Quality of facilities and school infrastructures. }\end{array}$ \\
\hline & $\begin{array}{l}1.4 . \\
\text { Professional } \\
\text { resources }\end{array}$ & $\begin{array}{l}\text { 1.4.1. Quantity and quality of school staff (e.g. teachers' professional career, teaching } \\
\text { experiences and proficiency, knowledge and skills available). }\end{array}$ \\
\hline \multirow{4}{*}{ 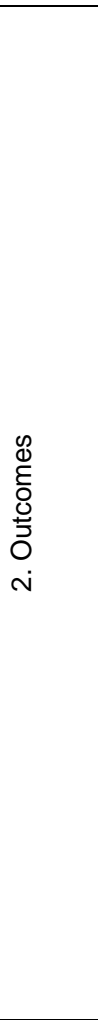 } & $\begin{array}{c}2.1 . \\
\text { School } \\
\text { outcomes }\end{array}$ & $\begin{array}{l}\text { 2.1.1. Results referred to students' short and medium term educational outcomes. It's } \\
\text { important that each school guarantees the appropriated learning support for all } \\
\text { students, school curriculum and educational success. }\end{array}$ \\
\hline & $\begin{array}{l}2.2 \text {. } \\
\text { Outcomes in } \\
\text { standardized } \\
\text { tests }\end{array}$ & $\begin{array}{l}\text { 2.2.1. Analysis of the results achieved in national standardized tests allows schools to } \\
\text { reflect on their level of expertise in relation to other local schools, at least to those } \\
\text { ones with similar socio-economic background, and the national average. This } \\
\text { analysis also helps to evaluate the ability of schools to ensure all students the } \\
\text { achievement of basic skills (literacy and numeracy). The action of the school should } \\
\text { therefore be aimed at reducing the incidence of learning gaps for students with low } \\
\text { learning levels, considering the outcome variability within the school (between } \\
\text { classes, typologies of studies, specific school curriculum of studies, as well as the } \\
\text { distribution of students across the different levels of performance). }\end{array}$ \\
\hline & $\begin{array}{l}\text { Key. } \\
\text { Key skills } \\
\text { and citizenship } \\
\text { competences }\end{array}$ & $\begin{array}{l}\text { 2.3.1. Key competences, including soft-skills, considered essential for full citizenship. } \\
\text { These include, for example, social and civic competences (compliance, ability to } \\
\text { create positive relationships with others, the construction of the sense of legality, } \\
\text { development of the ethics of responsibility and values in line with the constitutional } \\
\text { principles) and personal life-skills related to the ability to orient themselves and to act } \\
\text { effectively in different situations. It also seems important to consider students' } \\
\text { self-regulation ability in managing school work and study career. }\end{array}$ \\
\hline & $\begin{array}{l}2.4 . \\
\text { Long-term } \\
\text { outcomes and } \\
\text { follow up }\end{array}$ & $\begin{array}{l}\text { 2.4.1. Actions that schools define to provide long-term outcomes in following courses } \\
\text { of study (University, Higher Institutes of Technical \& Vocational Training, etc.) or } \\
\text { entering the labour force. It is, therefore, important to collect data about students' } \\
\text { learning outcomes after they complete lower or upper secondary school, as well as } \\
\text { monitor their learning results in the transition to further levels of schooling. } \\
\text { For upper secondary schools, significant indicators refer to student university } \\
\text { enrolment, college credits earned during the first and second post-diploma years; for } \\
\text { lower secondary schools available indicators are related to student success in } \\
\text { subsequent upper secondary studies and school/vocational education. }\end{array}$ \\
\hline \multirow{2}{*}{ 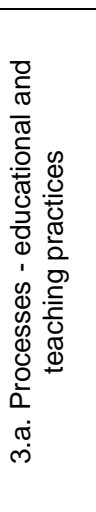 } & $\begin{array}{c}3.1 . \\
\text { Curriculum } \\
\text { design } \\
\text { and } \\
\text { assessment }\end{array}$ & $\begin{array}{l}\text { 3.1.1. Curriculum design at school level, focusing on the abilities and competences } \\
\text { required to meet community expectations. Definition of learning objectives for } \\
\text { different school grades. Elective and optional activities for curriculum enrichment. } \\
\text { Types of instructional design, monitoring and review of educational projects. } \\
\text { Methods used to assess students' knowledge and skills. } \\
\text { School curriculum is defined here as the specific education offered by the school, } \\
\text { based on students' needs and characteristics, identification of skills and knowledge } \\
\text { that students must achieve in different fields and periods of their school career. } \\
\text { Instructional design is here defined as the set of methodological choices, educational } \\
\text { and teaching strategies collegially adopted by teachers. }\end{array}$ \\
\hline & $\begin{array}{l}\text { 3.2. } \\
\text { Learning } \\
\text { environment }\end{array}$ & $\begin{array}{l}\text { 3.2.1. Capacity of the school to create a learning environment for students' skills } \\
\text { development. The care of the learning environment affects both the structural and } \\
\text { organizational dimension (management of space, equipment, schedules and } \\
\text { timetables), the educational dimension (dissemination of innovative teaching }\end{array}$ \\
\hline
\end{tabular}




\begin{tabular}{|c|c|c|}
\hline & & $\begin{array}{l}\text { methods), and finally the relational dimension (development of a positive learning } \\
\text { climate, transmission of shared rules). }\end{array}$ \\
\hline & $\begin{array}{c}3.3 . \\
\text { Inclusion } \\
\text { and teaching } \\
\text { differentiation }\end{array}$ & $\begin{array}{l}\text { 3.3.1. Strategies adopted by the school for the promotion of inclusion and respect for } \\
\text { diversity, disability; teaching and learning adaptation, special needs recognition within } \\
\text { classroom work and other educational contexts. } \\
\text { This area is divided into two sub-areas: } \\
\text { 1. Inclusion - how to include students with disabilities, with special educational needs } \\
\text { and foreign students. Actions for the improvement and management of differences; } \\
\text { 2. Recovery and Enhancement - strategies so as to adjust teaching activities to each } \\
\text { student's educational needs. }\end{array}$ \\
\hline & $\begin{array}{c}3.4 . \\
\text { Continuity } \\
\text { and } \\
\text { orientation }\end{array}$ & $\begin{array}{l}\text { 3.4.1. Activities to ensure continuity of schooling. } \\
\text { Activities for school, vocational and professional students' orientation. } \\
\text { Orientation staff training. } \\
\text { This area is divided internally into two sub-areas: } \\
\text { 1. Continuity - actions taken by the school to ensure educational continuity in the } \\
\text { transition from one level of school to another; } \\
\text { 2. Orientation - actions taken by the school to guide students towards an awareness } \\
\text { of their aptitudes, capacities and in the choice of following studies. }\end{array}$ \\
\hline \multirow{3}{*}{ 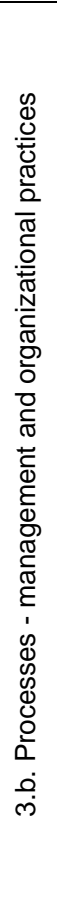 } & $\begin{array}{c}3.5 . \\
\text { Strategic } \\
\text { policies } \\
\text { and school } \\
\text { organization }\end{array}$ & $\begin{array}{l}\text { 3.5.1. Identification and sharing of common missions, values and vision of school } \\
\text { development. Success of schools in targeting resources on priorities, catalysing } \\
\text { intellectual energies, internal contributions and local resources. Financial and } \\
\text { material resources available for the achievement of organizational objectives. } \\
\text { The mission is here defined as the execution of the ministerial mandate within the } \\
\text { school context as well as membership: it is interpreted as a school autonomy } \\
\text { instrument. The mission is articulated in the Study Plan and is embodied in the } \\
\text { identification of priorities for action and educational activity implementation. }\end{array}$ \\
\hline & $\begin{array}{c}\text { 3.6. } \\
\text { Development } \\
\text { and human } \\
\text { resources }\end{array}$ & $\begin{array}{l}\text { 3.6.1. Capacity of the school to take care of staff professional skills, investing in } \\
\text { training and promoting an organizational environment to cultivate school human } \\
\text { resource capital. This area is divided internally into two sub-areas: } \\
\text { 1. Staff training - actions, financed by the school or by other agencies, for school staff } \\
\text { professional development (teachers, administrative employees, etc). } \\
\text { 2. Use of existing expertise - inventory of staff skills and their use. Collaboration } \\
\text { between teachers, teaching collegiality, activities in working groups, sharing tools and } \\
\text { educational/learning objects. }\end{array}$ \\
\hline & $\begin{array}{l}3.7 \\
\text { Integration and } \\
\text { relationship } \\
\text { with local } \\
\text { authorities } \\
\text { and students' } \\
\text { families }\end{array}$ & $\begin{array}{l}\text { 3.7.1. Capacity of the school to act as a strategic partner in territorial networks and } \\
\text { coordinate the various stakeholders who have responsibility for education policies at } \\
\text { local level. Ability to involve families as collaborative partners in the school project. } \\
\text { This area is divided internally into two sub-areas: } \\
\text { 1. Collaboration with the territorial networks and local authorities - promotion of } \\
\text { networks and agreements with territorial institutions and political bodies for training } \\
\text { purposes. } \\
\text { 2. Family involvement - ability to deal with families for the identification of educational } \\
\text { projects/activities, organization and school life. }\end{array}$ \\
\hline
\end{tabular}

The ISSEMod Model has been tested in 58 schools throughout Tuscany both to validate the methodological framework and to experiment the indicators set. It has been developed mainly to enrich the model established at national level, considering areas of interest and indicators that can be adapted to the specific nature of each school in order to effectively cope with school population demands. For this reason, the ISSEMod also provides indicators that schools are free to choose so as to evaluate the organizational and educational activities that best characterize their institutional identity (Simons, 2002). In this regard, the model pays special attention to the identification of educational interventions aimed at the construction of key competences for citizenship, in accordance with the Recommendation of the European Parliament and of the Council (2006, Table 1, area 2.3). The added-value that this model brings is the opportunity to negotiate, directly with schools, some indicators on which self-evaluation can be built up, so as to make the model useful and "tailor-made".

The indicators provided are important information tools, if used for deeper reflection with the objective of achieving a better understanding of the school. They allow each school to compare its situation with external benchmarks, supporting the self-evaluation of staff so as to be able to express an opinion on each area which is articulated in the Self-Evaluation Report. The judgments do not have to derive from the simple reading of the quantitative values provided by the indicators, but thanks to their interpretation and the reflection promoted by those who operate within the school and the stakeholders. On the other hand, it is necessary that the opinions expressed be explicitly justified in order to clarify the existing connection between the indicators and the data available. 
To analyse in more detail the areas and indicators included in the general model, schools are supported in the use of different sources of information. The information, in fact, can be made accessible through the Electronic System of the Ministry of Education available in the majority of European countries, the school report released by National Standardized Tests, satisfaction questionnaires for school teachers, head-masters, parents and students submitted directly by the schools. The analysis of indicators is made easier by some guiding questions. The latter represent a stimulus to reflect on the results achieved by the school in that specific sector. Starting with the reading of the indicators, the guiding questions ask schools to reflect on specific aspects so as to fill in what has been achieved in all areas, focusing specifically on the outcomes achieved and identifying strengths and weaknesses. In order to clarify the supporting function of the guiding questions, we indicate below some questions referred to area 3.2. "Learning environment" (Table 2).

Table 2. Example of Guiding questions to support reflection on SSE indicators

\begin{tabular}{|c|c|}
\hline Indicators & Guiding questions \\
\hline $\begin{array}{l}\text { 3.2.1.a } \\
\text { Lesson } \\
\text { duration }\end{array}$ & $\begin{array}{l}\text { What does the school do to guarantee the presence of laboratories (number of labs, identification } \\
\text { of teachers with function of coordination, state-of-the-art instruments, experimental materials, } \\
\text { etc.)? }\end{array}$ \\
\hline $\begin{array}{l}\text { 3.2.1.b } \\
\text { School time } \\
\text { and } \\
\text { Scheduling }\end{array}$ & $\begin{array}{l}\text { Have students an equal opportunity to use school laboratories and take part in experimental } \\
\text { activities? } \\
\text { Are there learning aids easily accessible in the classrooms (classroom library, computers, tablets, } \\
\text { interactive assets, books, aids for expressive and scientific activities, etc.)? } \\
\text { Does the school manage teaching time and schedule as resources for learning? } \\
\text { Is the articulation of school hours adequate for students' learning needs? } \\
\text { Does the lesson duration meet students' learning needs? }\end{array}$ \\
\hline $\begin{array}{l}\text { 3.2.1.c } \\
\text { Activities } \\
\quad \text { and } \\
\text { teaching } \\
\text { strategies }\end{array}$ & $\begin{array}{l}\text { e school promote the use of innovative teaching methods? } \\
\text { e school promote collaboration among teachers for the application of innovative teac } \\
\text { s? } \\
\text { e school use ICT in ordinary teaching activities? } \\
\text { hers attend training programs on innovative teaching methodologies? } \\
\text { systematic procedure exist to monitor teaching effectiveness? }\end{array}$ \\
\hline $\begin{array}{l}\text { 3.2.1.d } \\
\text { Discipline } \\
\text { and } \\
\text { behaviour }\end{array}$ & $\begin{array}{l}\text { How does the school promote common rules of behaviour among students? } \\
\text { In case of disciplinary problems, what are the actions promoted by the school? Are these actions } \\
\text { effective? } \\
\text { What does the school do to prevent deviant behaviour and antisocial attitudes? }\end{array}$ \\
\hline $\begin{array}{l}\text { 3.2.1.e } \\
\text { School } \\
\text { climate }\end{array}$ & $\begin{array}{l}\text { Does the school adopt specific strategies to promote social skills (e.g. assignment of roles and } \\
\text { responsibilities, care activities of common areas, development of a sense of legality and ethics of } \\
\text { responsibility, collaboration and team spirit, etc.)? } \\
\text { Are these activities referred to all students? }\end{array}$ \\
\hline
\end{tabular}

Considering the information collected for each indicator for the areas of Outcomes and Processes, schools can then express an overall judgment on the entire area, synthesized from the level reported in an assessment rubric using a scale of possible situations ranging from 1 to 7 . The situations 1 (very critical), 3 (with some critical aspects), 5 (positive) and 7 (excellent) shall be accompanied by an analytical description. The descriptions are not meant to be a picture of the situation of each school. They must be considered rather as a guide to understanding what is the best allocation of the school along the scale. Situations 2, 4 and 6 are not described and allow the school to place itself finding a correspondence between the description and the actual situation in relation to the considered aspects. For example, a school may choose to state 4 if it thinks that its situation is in some respects positive (5) while others present some critical points (3). For each area, one is required to provide a short explanation of the reasons for the choice of the judgment it gives for itself, including the factors or elements that have determined the location of the school on a specific level of the scale.

At the end of each area of Outcomes and Processes, some space has been added for an open text, where the school is required to argue why it has assigned itself a certain level in the assessment scale. To fill in this part, the following general criteria are suggested for consideration: 1 . Completeness - use of data and indicators made available by central institutions and ability to support the judgment identifying additional evidence together with data available for the school; 2. Accuracy - data and indicators read in a comparative perspective: comparing the current situation of the school with the benchmarks provided by the system (national and regional averages, general performance of the schools of reference in each area, etc.); 3 . Quality analysis - the data analysis takes into account the specificity of the context, highlighting the strengths and weaknesses of the school and identifying strategic issues.

All the information referred to the different areas mentioned above are included in a school report called the Integrated Self-Evaluation Report (ISER). The final section of the Report allows schools to identify the priorities on which they will act in order to improve their outcomes, and the long-term objectives which will constitute the basis of the improvement plan. The priorities that the school sets must necessarily relate to the students' 
learning outcomes. It is necessary to specify among the four areas of the outcomes, the one the school intends to deal with (1. school outcomes, 2. outcomes in national standardized tests, 3 . key skills and citizenship competences, 4. long-term outcomes and follow up) and to articulate which priorities the school wants to pursue (e.g. early school leaver reduction; reduction of the variability between classes; development of social skills, etc.). Long-term objectives (3 years) affect the results expected in relation to the strategic priorities. They identify in an observable and/or measurable way the content of priorities, and represent the goals towards which the school tends in its action for improvement. For each priority identified, its long-term objective must be set. They therefore refer to the areas of students' outcomes (e.g. in relation to the strategic priority "early school leaver reduction", the long-term objective may be defined as "to bring early school leaver percentage within $8 \% "$ ). To pursue the long-term objectives of the ISER, the school needs to work on the process objectives, defining the activities that the school intends to put into practice to achieve the strategic priorities identified. They represent the operational objectives to be achieved in the short-term (one school year) and can be related to one or more areas of the SEAIS.

\section{CONCLUSION}

The considerable number of interventions being developed by governments and trans-national bodies gives an indication of the seriousness with which the development of school self-evaluation capacity is now viewed. As in this case, the majority of the methodologies proposed in the USA and Europe concentrate on either providing frameworks for schools to use for data collection and analysis, or enhancing the schools' ability to generate data relevant to its own operation.

This present research intends to integrate both approaches, combining national models with other more personalized devices which give schools the opportunities to develop their own frameworks. The ISSEMod Model intends to develop a transferable SSE framework which is able to value school autonomy, internal decision making procedures and cyclical processes of quality assurance. Even if many countries have finally elaborated national systems of school self-evaluation, what needs more support is the capacity of schools and teachers to genuinely see the developmental possibilities and, therefore, be willing to engage in internal analysis and evaluation processes aimed at achieving generative improvement.

As clearly emerges also from the present research, schools that are presently working on the development of school self-evaluation systems need to be encouraged internally and externally to improve their own practices, reinforcing the educational processes and establishing a closer engagement with the community around their school. In terms of school self-evaluation and quality of schools, our research, as that of others, has confirmed a significant relationship between the quality of the teaching-learning process and the application of systematic types of school self- evaluation. This indicates that schools with an advanced school self-evaluation system demonstrate higher quality as regards curriculum design, use of learning time, pedagogical and didactical performance of teachers, school climate, attention to students' educational needs, adoption of transformative management models and, finally, a higher quality of support and guidance for students.

All this highlights the importance of continuing to focus educational research on the experimentation of new theoretical and methodological models of school self-evaluation in order to develop more and more effective means of internal analysis, as well as intervention aimed at improving the quality of schools and education.

\section{REFERENCE LIST}

Akpe, C.S. and Afemikhe, O. A. (1991). School of Self-Evaluation: An Examination of the State of The Art in Nigeria. Studies in Educational Evaluation, vol. 17, 117-127.

Argyris, C. and Schön, D. A. (1978). Organisational Learning: A Theory of Action Perspective. Reading, Mass: Addison Wesley.

Barzanò, G. (2002). School self-evaluation: Towards a European dimension. European Journal of Teacher Education, 25(1), 83-100.

Blok, H., Sleegers, P. and Karsten, S. (2008). Looking for a balance between internal and external evaluation of school quality: Evaluation of the SVI model. Journal of Education Policy, 23(4), 379-395.

Brookover, W.B. et al. (1979). School Social Systems and Student Achievement: Schools Can Make a Difference. New York: Praeger.

Carnall, C.A. (1990). Managing Change in Organisations. New York: Prentice Hall.

Carnoy, M., Elmore, R. and Siskin, L.S. (2003). The New Accountability. High Schools and High Stakes Testing. New York: Routledge. 
Coe, R. (2002). Finding Out What Works: Evidence-based Education. Durham: Durham University Press.

Coleman, J.S., Campbell, E.Q., Hobson, C.J., McPartland, J., Mood, A.M., Weinfeld, F.D. and York, R.L. (1966). Equality of Educational Opportunity. Washington, DC: U.S. Government Printing Office.

Creemers, B.P.M. (1994). The Effective Classroom. London: Cassell.

Creemers, B.P.M. and Kyriakides, L. (2008). The Dynamics of Educational Effectiveness. London and New York: Routledge.

Dalin, P. (1993). Changing the School Culture. London: Cassell.

Earley, P. et al. (Eds). (1996). Improvement Through Inspection? Complementary Approaches to School Development. London: David Fulton.

Ellett, C.D. and Teddlie, C. (2003). Teacher evaluation, teacher effectiveness and school effectiveness: Perspectives from the USA. Journal of Personnel Evaluation in Education, vol. 17(1), 101-128.

European Commission (2004). Evaluation of Schools Providing Compulsory Education in Europe. Brussels: European Commission.

European Commission/ EACEA/Eurydice (2015). Assuring Quality in Education: Policies and Approaches to School Evaluation in Europe. Eurydice Report. Luxembourg: Publications Office of the European Union.

European Parliament and The Council of the European Union (2001). Recommendation of the European Parliament and of the Council of 12 February 2001 on European cooperation in quality evaluation in school education.

European Parliament and The Council of the European Union (2006). Recommendation of the European Parliament and of the Council of 18 December 2006 on key competences for lifelong learning.

Fitz-Gibbon, C.T. (1996). Monitoring Education Indicators, Quality and Effectiveness. London: Cassell.

Goldstein, H. et al. (1993). A multilevel analysis of school examination results. Oxford Review of Education, vol. 19(4), pp. 425-433.

Goldstein, H. and Thomas, S. (1996). Using examination results as indicators of school and college performance. Journal of the Royal Statistical Society, vol. 159, 149-163.

Goodlad, J. (1984). A Place Called School: Prospects for the Future. New York: McGraw Hill.

Harris, D.N. and Herrington, C.D. (2006). Accountability, standards, and the growing achievement gap: Lessons from the past half-century. American Journal of Education, 112, 209-238.

Hattie, J. (2009). Visible Learning: A synthesis of Over 800meta-analyses Relating to Achievement. London: Routledge.

Hofman, R.H., Hofman, W.H.A., Gray, J. and Daly, P. (2003). Institutional Contexts of Education Systems in Europe. A Cross-country Comparison of Quality and Equity. Boston: Kluwer Academic Press.

Hofman R.H., Hofman W.H.A. and Guldemond H. (2003). Effective families, peers and schools. A configurational approach. Educational Research and Evaluation, vol. 9(3), 213-237.

Hofman, R.H., Dukstra, N.J. and Adriaan Hofman, W.H. (2005). School self-evaluation instruments: An assessment framework. International Journal of Leadership in Education, vol. 8(3), 253-272.

Jakobsen, L., MacBeath, J., Meuret, D. and Schratz, M. (2003). Self-Evaluation in European Schools: A Story of Change. London: Routledge.

Janssesns, F.J.G. and Van Amelsvoort, G. (2008). School self-evaluations and school inspections in Europe: An exploratory study. Studies in Educational Evaluation, vol. 34, 15-23.

Leithwood, K. and Aitken, R. (1995). Making Schools Smarter. Thousand Oaks, CA: Corwin Press.

Leithwood, K., Aitken, R. and Jantzi, D. (2001). Making Schools Smarter: A System for Monitoring School and District Progress $\left(2^{\text {nd }}\right.$ ed.). Thousand Oaks, CA: Corwin Press.

Leithwood, K., Edge, K. and Jantzi, D. (1999). Educational Accountability: The State of the Art. International Network for Innovative School Systems (INIS). Gütersloh: Bertelsmann Foundation Publishers.

Levine, D.U. and Lezotte, L.W. (1990). Unusually Effective Schools. Madison, WI: the National Center for Effective Schools Research and Development. 
Lissitz, R. (2005). Value-added Models in Education: Theory and Applications. Minnesota: JAM Press.

MacBeath, J. (1999). Schools Must Speak for Themselves: The Case for School Self-Evaluation. London: Routledge-Falmer.

MacBeath, J. (2003). The Self-Evaluation File. Good Ideas and Practical Tools for Teachers, Pupils and School Leaders. Glasgow: Learning Files Scotland Ltd.

MacBeath, J., Meuretz, D., Schratz, M. and Jakobsen, L. B. (1999). Evaluating Quality in School Education. A European Pilot Project. Final Report. Bruxelles: European Commission.

McNamara, G. and O'Hara, J. (2008). Trusting Schools and Teachers: Developing Educational Professionalism through Self-Evaluation. New York: Peter Lang.

Mintzberg, H. (1979). The Structuring of Organizations. Englewood Cliffs, NJ: Prentice Hall.

Mortimore, P. (1994). The positive effects of schooling. In: Rutter M. (Ed.). Youth In The Year 2000: Psycho-social Issues and Interventions. Boston: Cambridge University Press.

Mortimore, P. et al. (1988). School Matters: The Junior Years. Somerset: Open Books.

Nevo, D. (Ed.). (2002). School-based Evaluation: An International Perspective. Oxford: Elsevier Science.

Newmann, F.M., King, M.B and Rigdon, M. (1997). Accountability and School Performance: Implications from restructuring schools. Harvard Educational Review, vol. 67, 41-74.

OECD (2005). Teachers Matter: Attracting, Developing and Retaining Effective Teachers. Paris: OECD Publishing.

OECD (2014a). Education at a Glance 2014. OECD Indicators. Paris: OECD Publishing.

OECD (2014b). Equity, Excellence and Inclusiveness in Education. Policy Lessons from Around the World. Paris: OECD Publishing.

Olssen, M., Codd, C. and O' Neill, A. (2004). Education Policy, Globalisation, Citizenship and Democracy. London: Sage Publications.

Reezigt, G.J. and Creemers, B.P.M. (2005). A comprehensive framework for effective school improvement. School Effectiveness and School Improvement, vol. 16(4), 407-424.

Reid, K., Hopkins, D. and Holly, P. (1987). Towards the Effective School. Oxford: Blackwell.

Reynolds, D. and Teddlie, C. (2000). The Process of School Effectiveness. In: Reynolds, D. \& Teddlie, C., (Eds). The International Handbook of School Effectiveness Research. London: Falmer Press.

Reynolds, D., Teddlie, C., Hopkins, D. and Stringfield, S. (2000). Linking school effectiveness and school improvement. In: Reynolds, D. \& Teddlie, C., (Eds). The International Handbook of School Effectiveness Research. London: Falmer Press.

Sammons, P. (1994). Findings from school effectiveness research: some implications for improving the quality of schools. In: Ribbins P. and Burridge E. (Eds). Improving Education: Promoting Quality in Schools. London: Cassell.

Scheerens, J. (2000), Improving School Effectiveness. Paris: UNESCO.

Scheerens, J. (2002). School self-evaluation: Origins, definition, approaches, methods and implementation. In: D. Nevo (Ed.), School-based evaluation: An international perspective. Oxford: Elsevier Science.

Scheerens, J., Glas, C.A.W., Thomas, S.M. and Thomas, S. (2003). Educational evaluation, assessment, and monitoring: a systemic approach, vol. 13, Taylor \& Francis.

Scheerens, J. and Hendriks, M. (2004). Benchmarking the quality of education. European Educational Research Journal, vol. 3(1), 101-114.

Simons, H. (2002). School self-evaluation in a democracy. In: Nevo D. (Ed.). School-based Evaluation: An International Perspective. Oxford: Elsevier Science.

Stoll, L. and Fink, D. (1996). Changing Our Schools: Linking School Effectiveness and School Improvement. Buckingham: Open University Press.

Stoll, L. and Wikeley, F. (1998). Issues on linking school effectiveness and school improvement. In: Hoeben W.T. (Ed.). Effective School Improvement: State of the Art Contribution to a Discussion. Groningen: 


\section{GION/RUG.}

Stringfield, S., Reynolds, D. and Schaffer, E.C. (2001). The High Reliability Schools Project. Paper presented at the ICSEl, Toronto, 2001.

Stringfield, S. and Slavin, R. (2001). Compensatory Education at the Crossroads, Sociocultural, Political, and Historical Studies in Education. Mahwah, NJ: Lawrence Erlbaum Association.

Stufflebeam, D.L. (2000). The CIPP model for evaluation. In: Stufflebeam, D.L., Madaus, G. F. and Kellaghan, T. (Eds.). Evaluation Models ( $2^{\text {nd }}$ ed.). Boston: Kluwer Academic Publishers.

Thomas, G. and Pring, R. (Eds.). (2004). Evidence-based Practice in Education. Maidenhead: Open University Press.

Wastiau-Schlüter, P. (Ed.). (2004). A Close-up on the Evaluation of Schools. Brussels: Eurydice.

West, M. and Hopkins, D. (1997). Using Evaluation Data to Improve the Quality of Schooling. Frankfurt, Germany, ECER-Conference.

Wilcox, B. and Gray, J. (1996). Inspecting Schools: Holding Schools to Account and Helping Schools to Improve. Buckingham Philadelphia: Open University Press.

Woessmann, L., Luedemann, E., Schuetz, G. and West, M.R. (2009). School Accountability, Autonomy and Choice around the World. Cheltenham, UK/Northampton, MA, USA: Edward Elgar. 